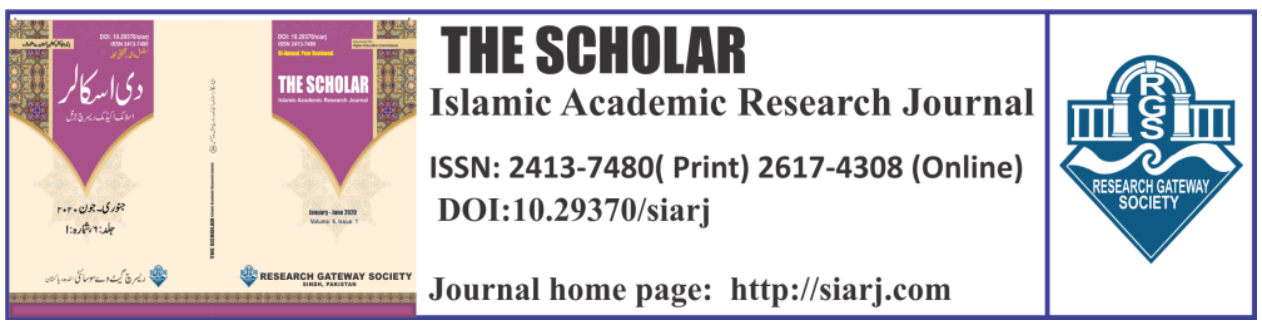

\title{
ECONOMIC IMPACTS OF ISLAMIC MADRASSAS EDUCATION ON THE PEOPLE OF LARKANA DIVISION
}

\section{Jalil Ahmed}

Ph.D. Research Scholar, Shah Abdul Latif University, Khairpur, Sindh, Pakistan; Assistant Professor Mehran University of Engineering \& Technology, SZAB Campus, Khairpur, Sindh, Pakistan Email: Jalilahmed@ muetkhp.edu.pk

\section{https://orcid.org/0000-0002-0800-8010}

\section{Imdad Hussain Sahito}

Professor Shah Abdul Latif

University, Khairpur, Sindh, Pakistan

Email: imdadsahitodr@gmail.com

ORCID ID:

https://orcid.org/0000-0002-0800-8010

\section{Amir Ahmed Khuhro}

Professor, Shah Abdul Latif University, Khairpur, Sindh, Pakistan.

Email: amir.khuhro@salu.edu.pk

ORCID IID: https://orcid.org/0000-0003-1797-2060

To cite this article:

Chandio, Jalil Ahmed, Imdad Hussain Sahito, and Amir Ahmed Khuhro. "ECONOMIC IMPACTS OF ISLAMIC MADRASSAS EDUCATION ON THE PEOPLE OF LARKANA DIVISION." The Scholar-Islamic Academic Research Journal 7, no. 1 (June 30, 2021). 13-31.

To link to this article: https://doi.org/10.29370/siarj/issue12ar2

Journal

Publisher

DOI:

URL:

License:

Journal homepage

Published online:
The Scholar Islamic Academic Research Journal Vol. 7, No. 1 ||January-June 2021 || P.13- 31

Research Gateway Society

10.29370/siarj/issue12ar2 https://doi.org/10.29370/siari/issue12ar2

Copyright c 2017 NC-SA 4.0

www.siarj.com

2021-06-30
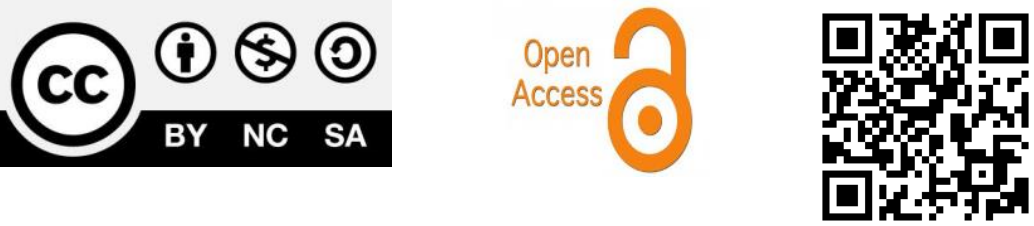
THE SCHOLAR (January - June 2021)

\title{
ECONOMIC IMPACTS OF ISLAMIC MADRASSAS EDUCATION ON
} THE PEOPLE OF LARKANA DIVISION

Jalil Ahmed, Imdad Hussain, Amir Ahmed Khuhro

\begin{abstract}
:
This study aims to determine the economic impacts of the education system of madrasas on the people of the Larkana division. Planned this research in such a way as to embody the following subjects Research Design, Research techniques, target Population, test, and examining systems, explore instruments, information accumulation, and information investigation methods. He adopted the qualitative research design because it permitted the direct researcher experience within the research field to deepen his understanding of what he was studying. 1. It is believed Pakistan's Islamic madrassas are the factory of Jihad. Still, present studies rejected the already given findings by international researchers, but the current study also proved that madrasas are the source of economy for the people associated with madrasas; these findings are on Larkana district of Sindh province of Pakistan. Students who were getting an education in Larkana district's madrassas district were from a poor background with no economic support from their families. Still, after passing out from Madrassa, most students were found enough economically wealthy that they were in a position to support their families. It was due to their education from madrassas of the Larkana
\end{abstract}

\footnotetext{
${ }^{1}$ John W Creswell and Vicki L Plano Clark, "Creswell\&Clark_Chap4\&5.Pdf," Designing and Conducting Mixed Methods Research, 2007.
} 
THE SCHOLAR (January - June 2021)

district. The application of the present study will be helpful for Pakistan and international powers to look into another side of madrassas and their education system; it will help eliminate poverty, terrorism, and extremism. The present study explores the economic impacts of madrassas on the people associated with the madrassa education system; furthermore, this study is on the financial implications of madrassa education Larkana district.

KEYWORDS: Madrassa, Jihad, Education, Economic Impacts, Larkana

\section{INTRODUCTION:}

Islam is the religion based on knowledge and that knowledge without education is not possible there are number of Hadith about the education, Prophet Mohammad preached for education.

Education is the not only right, but it is the duty of every Muslim, male and female.(Source: Al Trimidhi)

At another place Hadith describes as the

Knowledge can't be acquired with sloth.(Source: Muslim Hadith) in the light of these hadith the education system was promoted by prophet Mohammad (SAWW).

The madrassa education is connected with these hadith the madrassas promoted education wither male or female. If we discuss on madrassa education the Madrassas give free religious education in the Islamic Republic of Pakistan, mostly with free housing and boarding; it is witnessed that poor and orphans do not pay a single penny. The Madrassa is the institution that provides Islamic teachings in the country without any 
cost. In earlier times, these had been the wellspring of the Islamic Nobel customary instruction framework ${ }^{2}$ since the entry of Islam in the Arab world. It became law in Pakistan the Madrassa Sanads (degrees) were made equivalent to modern education like M.A during the time of Military ruler General Mohammad Zia-ul-Haq (5 ${ }^{\text {th }}$ July 1977-88). Due to that legislative order, the Madrassas were urged to gain administrative positions in-country at a more significant level. This exertion further energized the honors and caretakers of madrasas to send their youngsters as best advance for them. In notable cases, numerous kids with one same family were shipped off strict schools, for example (Madrassa) and along these lines got colossal state support in setting up Madrassas. After the most noticeably awful psychological militant's assaults of $9 / 11$, this strict schooling arrangement of Pakistan procured a unique consideration worldwide.

Interestingly the strict instruction arrangement of Pakistan became prey to the analysis by the world and their scholastics, and journalists started to compose on the rigid schooling foundations in Pakistan. The primary spotlight has been on their contribution to psychological oppression, partisan viciousness, and strict fundamentalism. While glancing into harsh, political, social, fanatic elements of Madrassas, scarcely any scientists principally chipped away at training with the social and financial setting of Madrassas also. After 9/11, several exploration papers, books, working papers, and narratives arrived at an overall resolution for Madrassa teachings in the Islamic Republic of Pakistan.

${ }^{2}$ P W Singer, "Pakistan's Madrassahs: Ensuring a System of Education Not Jihad," Analysis Papers, no. November (2001). 
About one-third of youngsters do not go to schools, both public or nonpublic schools, and they primarily fit themselves in these religious schools (the Madrassas).

Of Pakistan in various parts of the country, and these strict foundations are mainly profoundly established with severe and nearby socio-economic ties. In addition, these Madrassas included themselves in the socialeconomical and politics. Political focuses have extraordinary significance in Pakistan's political framework ${ }^{3}$.

The Sindh has created acclaimed Sufi holy people the popular among them are the Usman Marwandi (known as the Lal Shahbaz Qalandar of Shewan Shariff ), poet Shah Abdul Latif popularly known as Shah Bhittai of Bhit Shah, a town near Hala Sindh in Hyderabad Division, and the Abdul Wahab popularly known as Hazrat Sachal Sarmast of Daraza Sharif in district Khairpur. Since the commencement, the Sindh land has been more disposed towards Sufism. Even though Islam involves the focal spot, individuals are slanted towards the Sufism and spiritualist customs and could be accepted that they are less strict. The term less severe ought not to be misjudged as in they are not Muslims anymore. Close to being Muslim, they impacted the neighborhood customs, for example, the way of life and Sufism. In this manner, the current examination project is proposed to discover the economic effects of madrassas training in the Sindh territory of Pakistan by zeroing in, especially on the Larkana area.

\section{LITERATURE REVIEW:}

The Madrassas instruction learning is old. A few researchers link the

${ }^{3}$ Ali Riaz, "Faithful Education: Madrassahs in South Asia," Faithful Education: Madrassahs in South Asia, 2008, https://doi.org/10.1057/ejdr.2010.7. 
madrasas education back to Holy Prophet Muhammad (SAAWS), and others follow it back to just the long term. Over the years, Madrassas filled in as a wellspring of strict instruction inside the Muslim social orders. It is regular in practically all Muslim nations as an arrangement of training and an abundance of rigorous education. Madrassas existed before the foundation of the country. In 1947 the Madrassa were numbered 137 to $139^{4}$. This number increased to 244 in West Pakistan only (presently known as Pakistan), as indicated by the 1956 study $^{5}$. The exact number of madrassas is unknown today. The Government of Pakistan today points that there are hardly 10,000. Still, the independent organizations count these madrasas more than the number told by the government, and they count nearly forty-five thousand in number ${ }^{6}$.

The Global Crisis Gathering's report of 2002 assessed that in Pakistan, there are around 47000 Madrassas. After 9/11, the Madrassa of Pakistan got global attention, and it is considered that their curriculum is outdated and is of no use as per today's needs.

The madrassas of Pakistan are as old as the independence of the country. Madrassa of Pakistan after 1979 fixed themselves into sectarian and political lines. Further, the Madrassas are considered the social welfare organizations. They are known as civil society - the Madrassa are active within their limited resources they are found involved in the activities like economic growth, religiopolitical social welfare ${ }^{7}$ ). The considerable

\footnotetext{
${ }^{4}$ Singer, "Pakistan's Madrassahs: Ensuring a System of Education Not Jihad."

${ }^{5}$ Jamal Malik, Colonialization of Islam: Dissolution of Traditional Institutions in Pakistan (New Delhi: Manohar, 1996).

${ }^{6}$ Singer, "Pakistan's Madrassahs: Ensuring a System of Education Not Jihad."

${ }^{7}$ Riaz, "Faithful Education: Madrassahs in South Asia"; Saleem H Ali, "Islam and Education: Conflict and Conformity in Pakistan's Madrassahs," 2009.
} 


\section{Economic Impacts of Islamic Madrassas Education on the People of Larkana Division}

increase of madrassas witness during the Zia era throughout Pakistan. ${ }^{8}$.

The economic perspective madrassa is as essential as the militant view is considered for research. It roused me, and specialists took interest to learn about the economic impacts of Madrassas education and its outcomes for this investigation on the Larkana district of Sindh province of Pakistan for which Madrassas of various groups were taken for study.

\section{METHODOLOGY}

This research study was conducted through qualitative research method indepth interviews, ethnographic tools informal discussions completed this research includes the primary sources to find out first-hand data while for available literature secondary sources are essential.

The secondary sources are available articles, books, and monographs; the researcher approached the leading libraries of Pakistan to gather data that included the library of IPRI, Quaid-e-Azam University, the library of Shah Abdul Latif University, Shahnawaz Bhutto Library of Larkana.

\section{FINDINGS:}

During the present study, some findings of this study are given below, which need to be addressed. It is found that the economy and education is the factor which can improve the quality of life and that can reject the religious extremism from Pakistan. It will help enhance the knowledge of religion and give birth to religious scholars and the economic benefits to the people associated with these madrassas. Government must encourage the madrassas as HEC is promoting Degree awarding institutions in

${ }^{8}$ Malik, Colonialization of Islam: Dissolution of Traditional Institutions in Pakistan; Riaz, "Faithful Education: Madrassahs in South Asia"; Hassan Abbas, Pakistan's Drift into Extremism: Allah, the Army, and America's War on Terror, 2004; Husain Haqqani, Pakistan: Between Mosque and Military (Carnegie endowment, 2010). 
Economic Impacts of Islamic Madrassas Education on the People of Larkana Division

Pakistan.

\section{DISCUSSION:}

Before finding out the results of the economic impact of madrassas of the Larkana district, it is necessary to find out the status of madrassas of Sindh province. A detailed description is given below. In the report carried out by the Sindh government home department, there are 9590 madrasas in Sindh, out of which 3087 are unregistered Madrassas, as given below in figure I

Figure-I Madrassas in Sindh Province

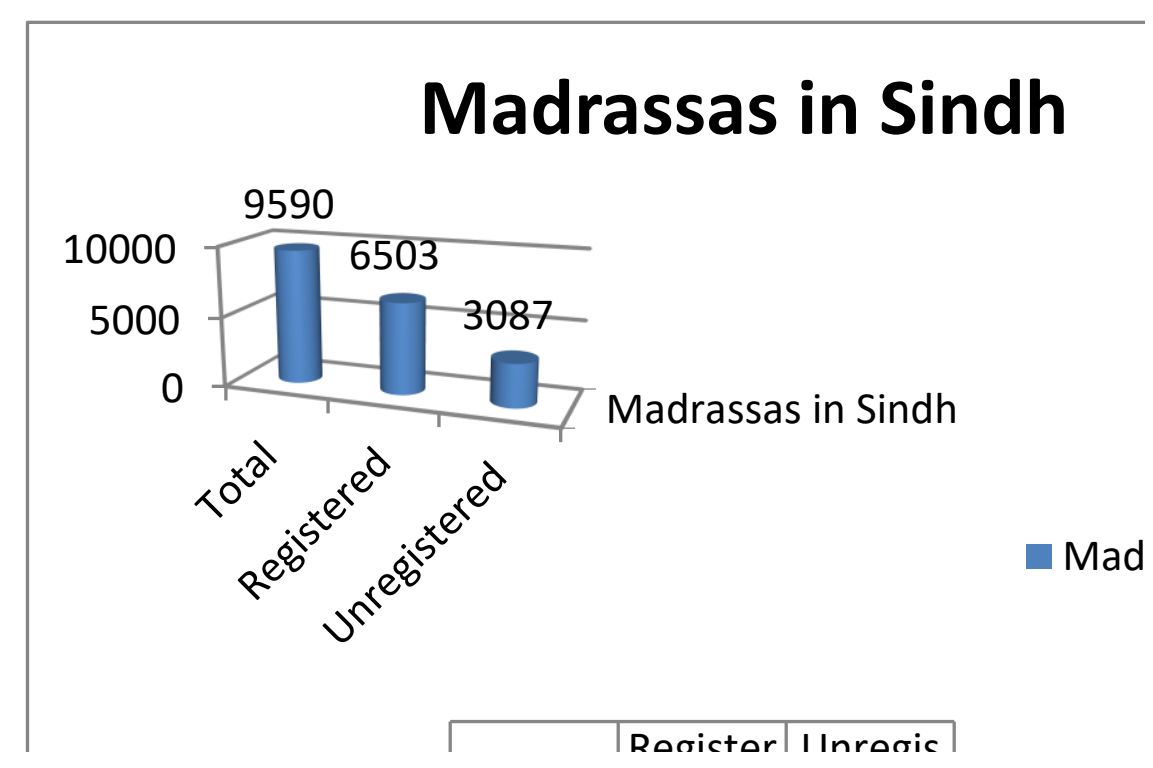

The madrasas of Sindh are further divided based on sect and sect was range wise registered Madrassas are also given the registered Madrassas of Deobandi are 2599, Barelvi sect have 3426, Shia sect have 192 and others 197 as in figure II 
Economic Impacts of Islamic Madrassas Education on the People of Larkana Division

\section{figure II Registered Madrassas in Sindh}

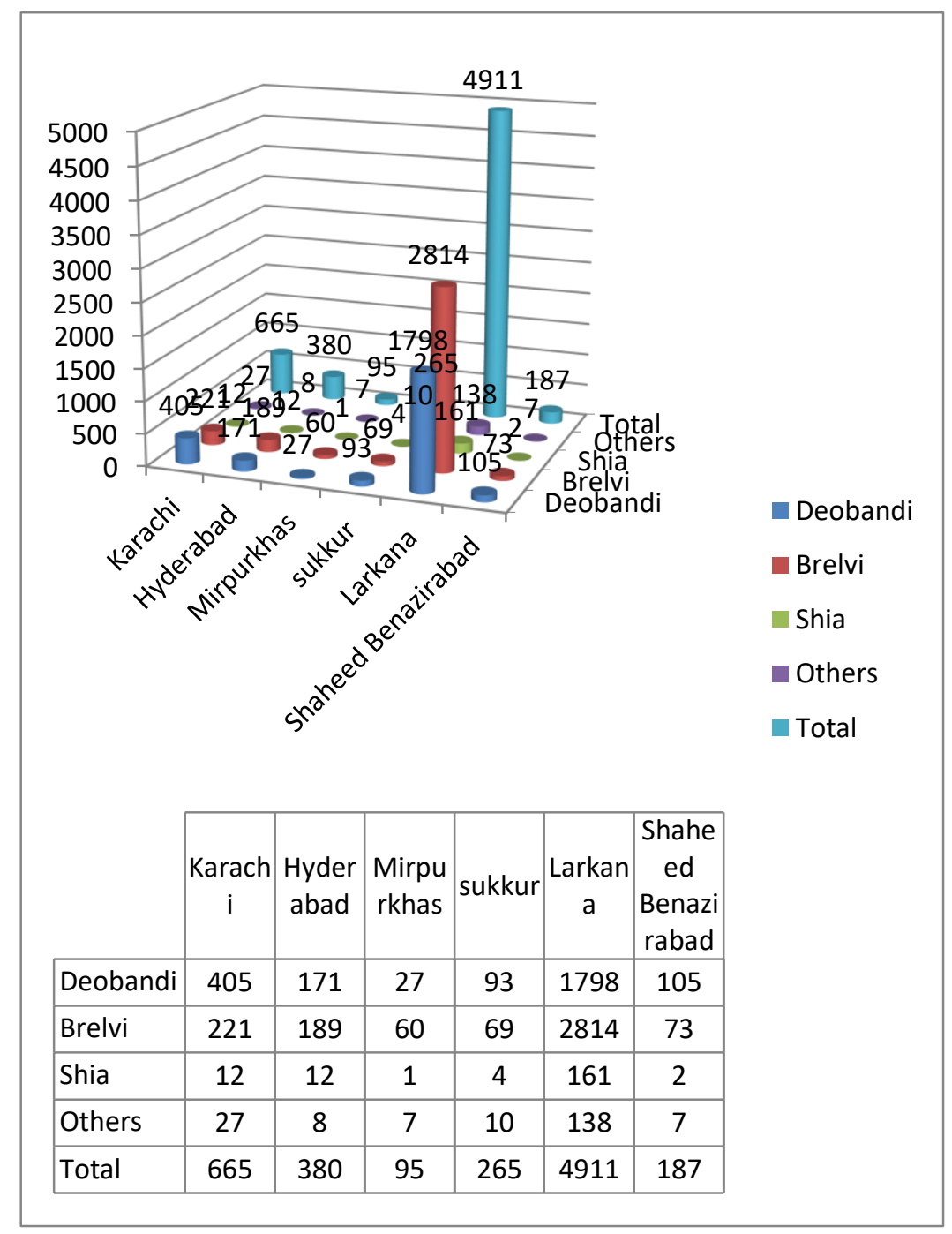

The total number of students in Madrassas of Sindh is 281976, out of which 28178 are local, and 228 are foreigners, as given in figure III.

Figure III shows the breakup of several students in registered Madrassas of Sindh. 
Economic Impacts of Islamic Madrassas Education on the People of Larkana Division

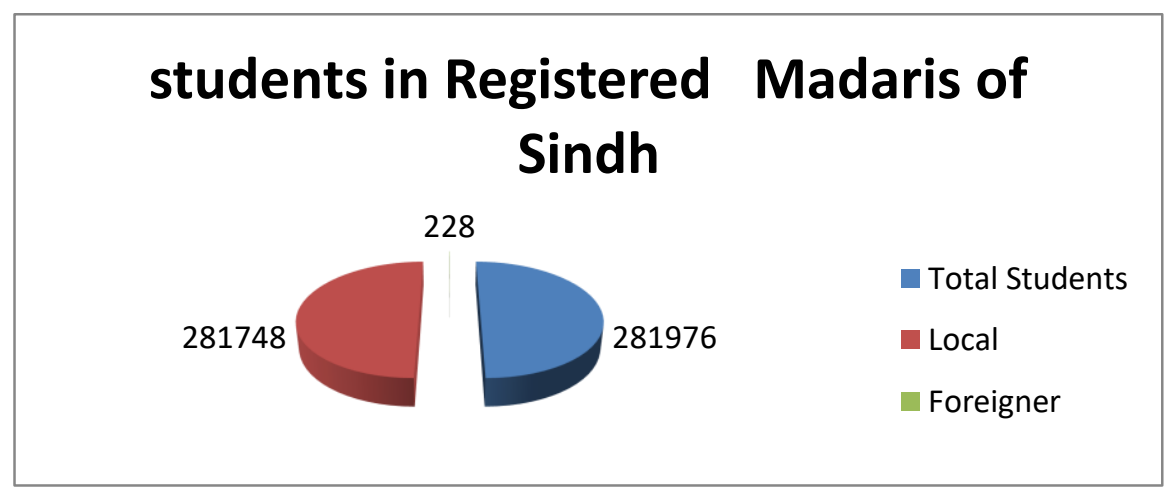

After the registered number of madrasas and the students, there are several unregistered madrassas in Sindh province which are functioning even today the statics is given by Crime monitoring cell reported by Inspector General of Police, Sindh home department government of Sindh as per report the number of unregistered madrassas in Sindh province as given, in Figure IV.

Figure IV shows the number of unregistered madrassas in Sindh Province. 
Economic Impacts of Islamic Madrassas Education on the People of Larkana Division

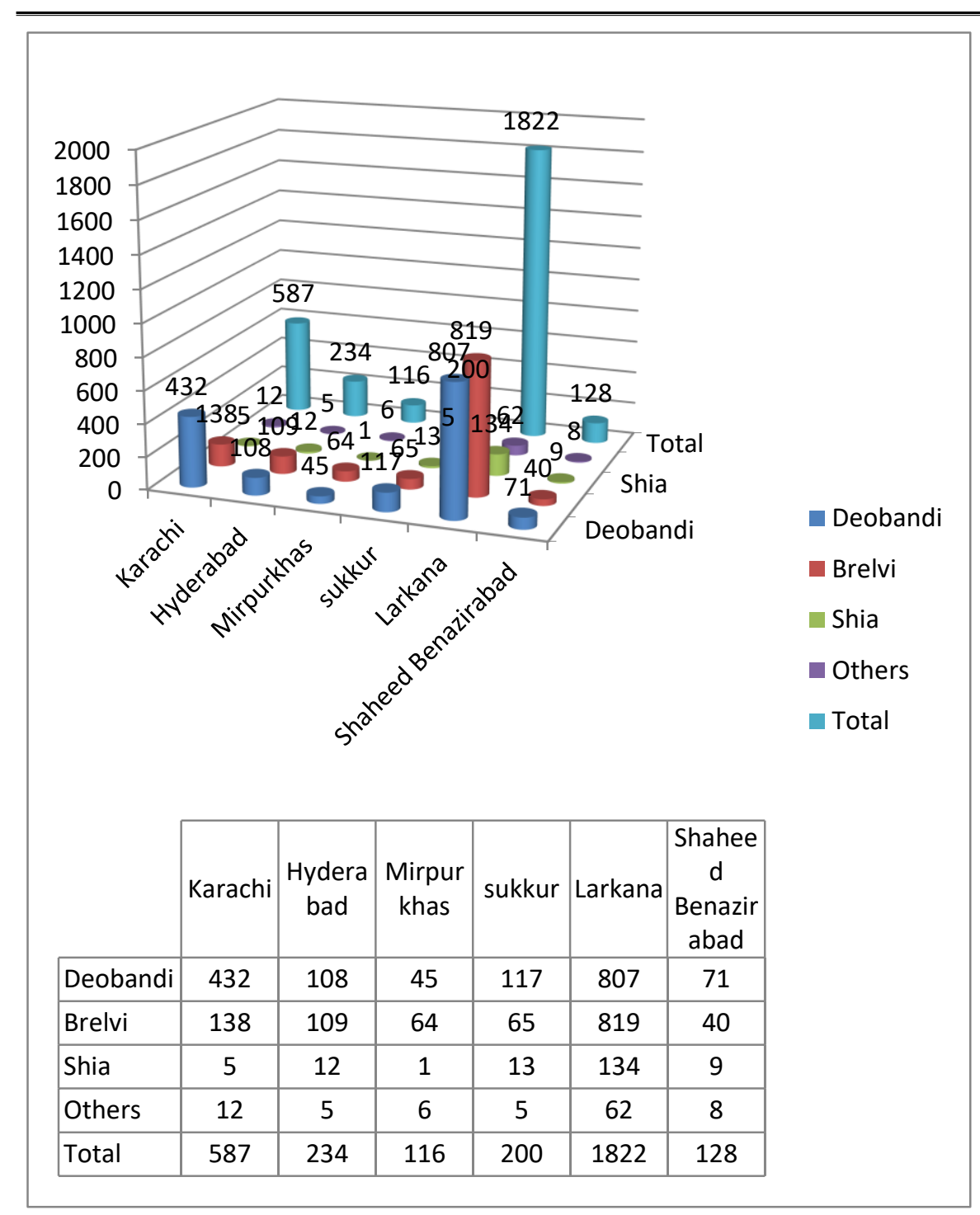

Apart from the unregistered madrasa, several students are getting an education in unregistered Madrasas of Sindh province. The under-given figure $\mathrm{V}$ shows the number of students in Sindh and the number of unregistered

students. 
The Scholar Islamic Academic Research Journal

Vol. 7, No. 1 || January -June 2021 || P. 1-31

https://doi.org/10.29370/siarj/issue12ar2

Figure V shows the students in unregistered madrassas in Sindh.

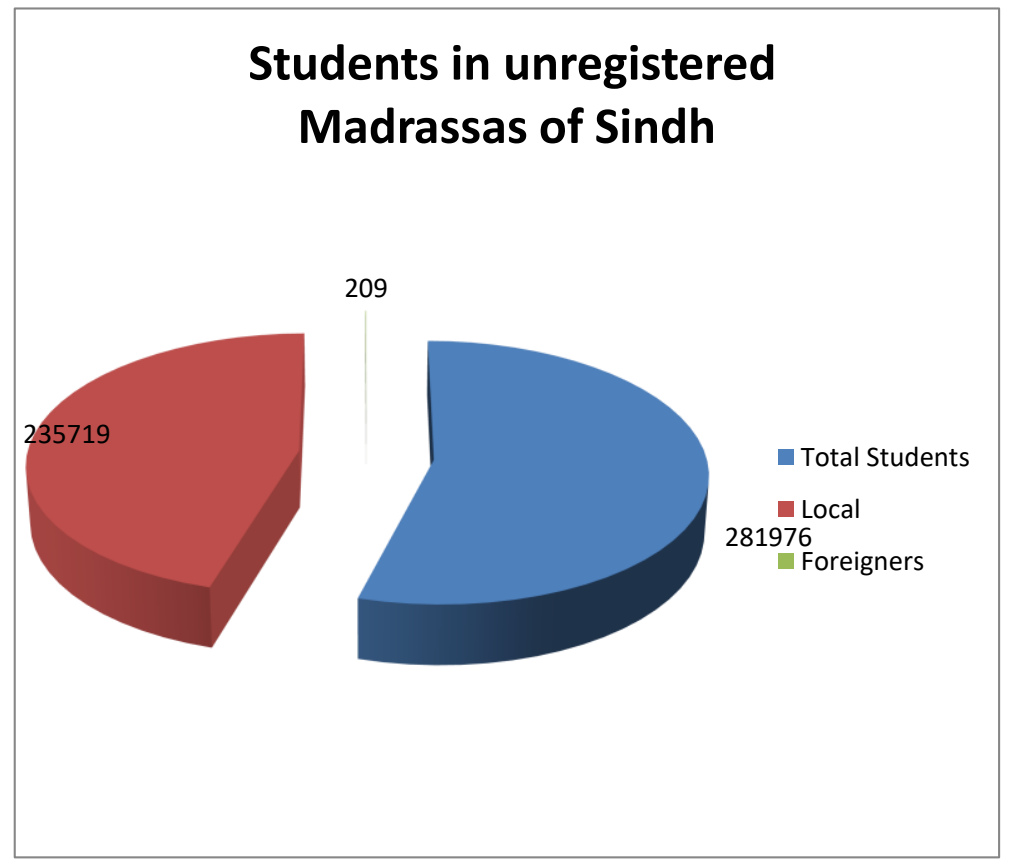

The above-given data is about the Madrassa of Sindh the total number of Madrassa of each sect and the unregistered madrasas in Sindh is also given further the number of students who are in registered and unregistered madrassas is also provided, the present study is to find out economic impacts of madrassas of Larkana district.

The number of registered and unregistered madrasas of the Larkana division is also given above, but shockingly, the number of madrassas is more significant in number in the Larkana division than other divisions of Sindh per their population. Figure VI Shows the statics of registered and unregistered Madrassa of the Larkana division. 
The Scholar Islamic Academic Research Journal Vol. 7, No. 1 || January -June 2021 || P. 1-31 https://doi.org/10.29370/siarj/issue12ar2

Figure VI Distribution of madrassas in Larkana division

\section{Registered madrassas in Larkana division as per sect}
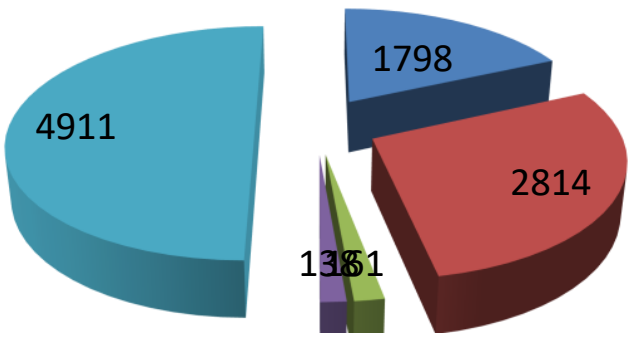

$$
\begin{aligned}
& \square \epsilon \\
& \square \bar{c} \\
& \text { Sh } \\
& -01 \\
& =T r
\end{aligned}
$$

The figure VII number of unregistered madrasa is given in Larkana division there are total 1822unregistred madrassas out of them 807 of deobandi school of thought are unregistered in Larkana division,819 unregistered madrasas are of Barelvi's,while 134 are of shia sect and 62 others. 
The Scholar Islamic Academic Research Journal Vol. 7, No. 1 || January -June 2021 || P. 1-31 https://doi.org/10.29370/siarj/issue12ar2

Figure VII shows the number of unregistered Madrassas in Larkana division.

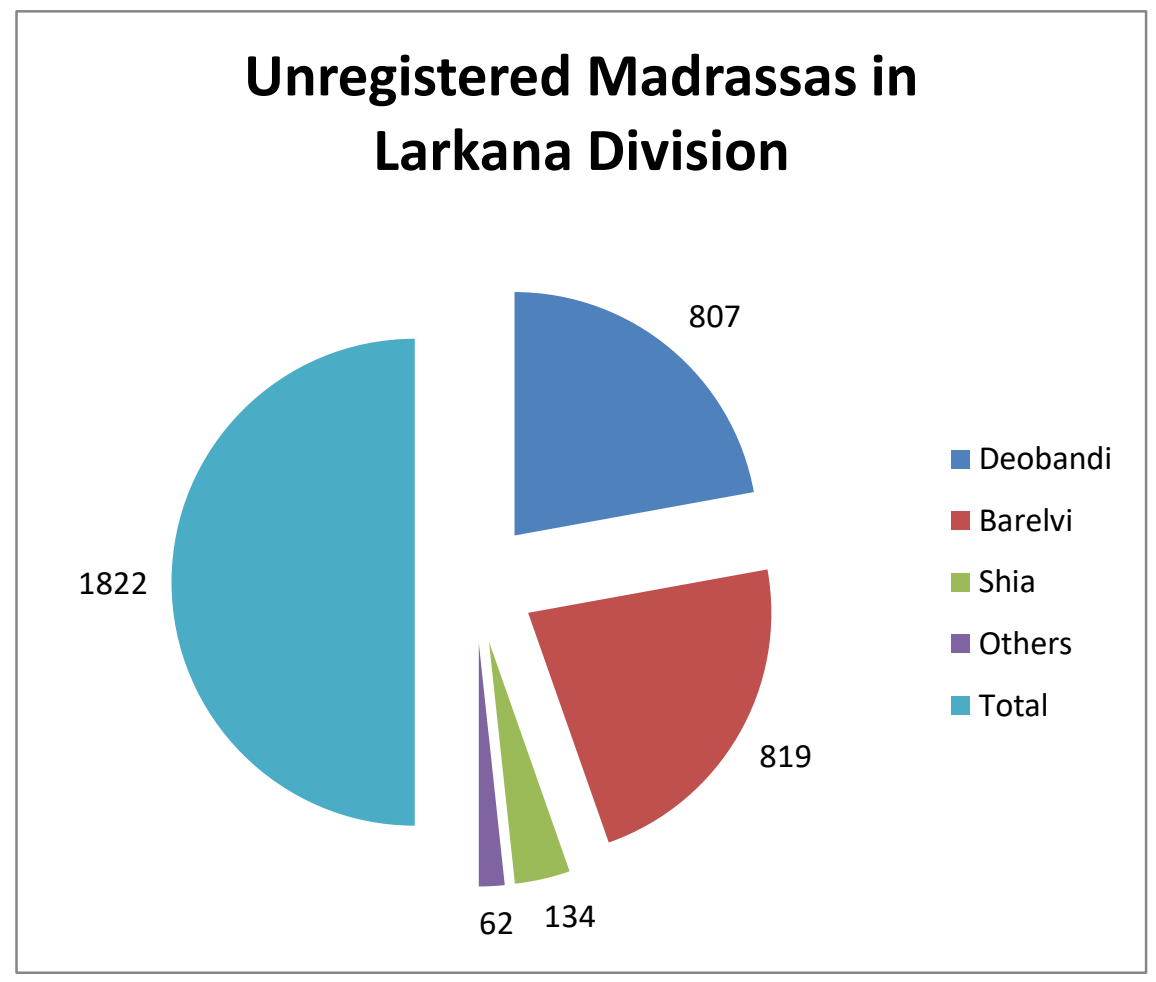

The total number of students in the madrassas of Larkana are 28240 and 17669 are in registered madrassas, and 10571 are in unregistered Madrassa of Larkana division figure VIII show the description.

Figure VIII Numbers of students in Madrassas of Larkana division.

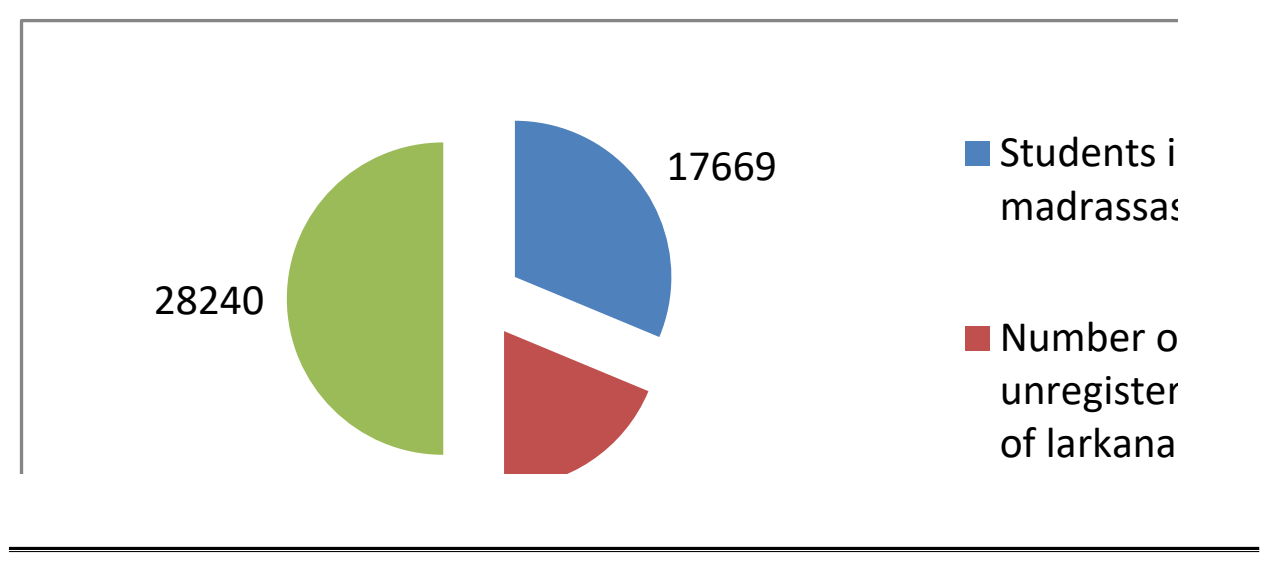


The total number of registered and unregistered Madrassas in Sindh province is 9590. After all further divided into the number of Madrassa as per sect, 4149 madrassas belong to Deobandi sects,4661 of Barelvi,366 belong to shia 295 others. Under given in figure IX shows the percentage of each sect regarding madrassas.

Figure IX shows the percentage of madrassas in Sindh as per their sect.

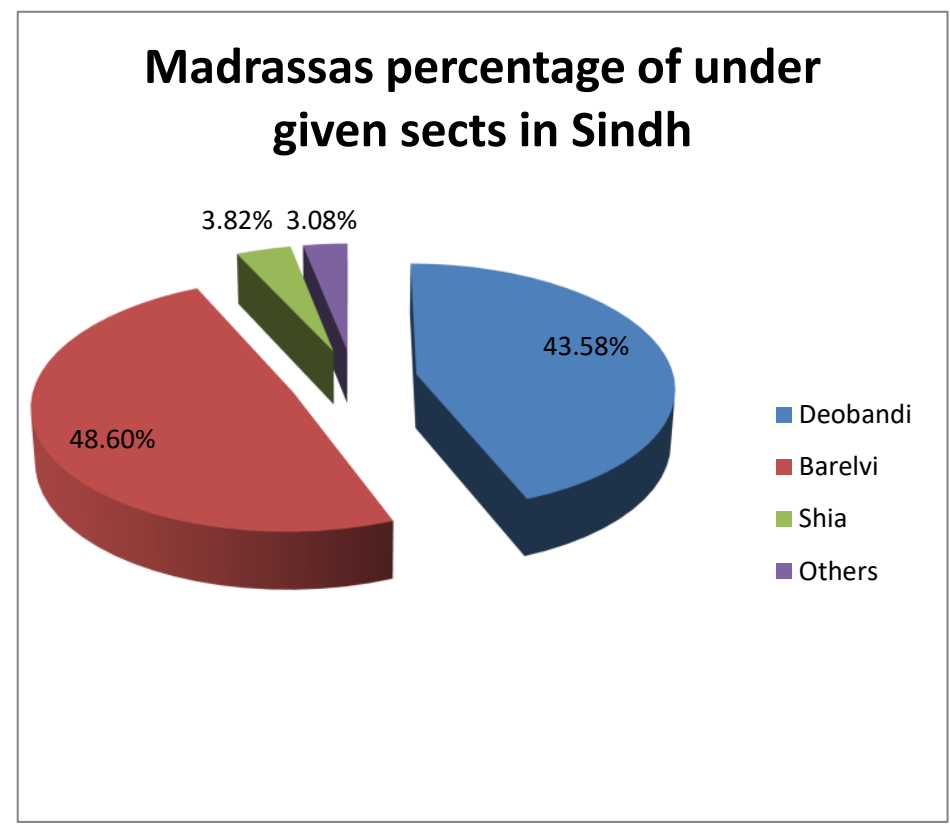

The above study is given on the madrasas of the Sindh province their distribution based on sect, the population of madrassas, and the division based on registered and unregistered, and This research finding is on 
The Scholar Islamic Academic Research Journal

Vol. 7, No. 1 || January -June 2021 || P. 1-31

https://doi.org/10.29370/siarj/issue12ar2

Larkana district, Larkana is the fourth largest city of Sindh province ${ }^{9}$ the description of madrassas of Larkana is given in figure VI, VII \& VIII. The researcher tried to find out the economic impacts of the madrassas of the Larkana district,

The researcher visited five madrassas of district Larkana. The researcher tried to cover madrasas of every sect to avoid any biases researcher framed questionnaire. Those questioners were translated into local language to get accurate findings; during the questionnaire filling up process, the researcher observed madrassas students, and informal interviews were also conducted to find out the results accuracy, the researcher focused on those madrassas where the majority of students were living inside the Madrassa and researcher himself stayed in madrasas and observed the madrassas students and environment of madrassas. The number of students was honored during a stay in madrassas that they were from poor background and economy was the main problem for them due to that they were in madrassas to get religious education after that they will be in a position to earn for their family. The table given below indicates sect wise visit of madrasas and the number of respondents.

9 Yasmin Bhurgri et al., "Cancer Profile of Larkana, Pakistan (2000-2002)," Asian Pacific Journal of Cancer Prevention 7, no. 4 (2006): 518. 
TABLE I. Sect Wise Breakup of Madrassas \& Response of Students

\begin{tabular}{|l|l|l|l|}
\hline S.NO & $\begin{array}{l}\text { NO. OF } \\
\text { MADRASSAS }\end{array}$ & $\begin{array}{l}\text { MADRASSAS } \\
\text { VISITED }\end{array}$ & RESPONDENTS \\
\hline $\mathbf{0 1}$ & Deo Bandi & 05 & 20 \\
\hline $\mathbf{0 2}$ & Barelvi & 05 & 13 \\
\hline $\mathbf{0 4}$ & Shia & 02 & 6 \\
\hline $\mathbf{0 5}$ & Ahl-e-Hadith & 01 & 4 \\
\hline
\end{tabular}

Source: Researchers field visit

Sect wise response of students about the economic impacts of madrasas is given in graph given below. The researcher conducted sampling and visited the above-numbered madrassas and conducted interviews and indepth observation to determine the response from the students and teachers of Madrassa. Figure IV shows the results of different madrasas students as per sect Deobandi madrassas students were of the view that $75 \%$ agrees that madrasas education helped them in terms of the economy after getting an education from madrasas, $70 \%$ Barelvi madrassas students believed that due to madrassas education their economic problems are resolved. They suggested that if one cannot get modern education, then a madrassa education is the key to success because, on one side being Muslim, they will get a madrassa education, and on another side, it is beneficial for them in terms of economy. The students belonging to shia madrasas their opinion was $67 \%$ of them are agree that madrasas impact the life of people in terms of economy, one can better earn after getting an education from madrassas, and he will be in a position to complete fill needs of his family after getting instruction from madrasas. In comparison, $75 \%$ of Ahle Hadith madrassas students agree that the economic impact is the main task 
The Scholar Islamic Academic Research Journal

Vol. 7, No. 1 || January -June 2021 || P. 1-31

https://doi.org/10.29370/siarj/issue12ar2

of madrasas. Without religious knowledge, one cannot be able to earn for his/her family.

The opinion of madrassa students was that the madrassas education system is as essential as the liberal or modern education system is essential. If one can't get an education in modern schools/colleges, he must get an education in madrassas because after getting instruction. Madrassa education helps to earn better as liberal education students make after completing their education.

During field visits, the researcher found that most madrassa teachers were with poor backgrounds and orphans and belonging to rural areas. Their views were that they earn 40 to 50 thousand per month, food shelter is free, live in madrassas, and their opinion was one can get education from madrassas to support his low-income family. Their view was that they live free of cost in madrassas, and a large amount of their earning is saved, and they send it to their homes. Figure $\mathrm{X}$ shows the sect-wise distribution of impacts of madrassas in the Larkana district.

\section{FIGURE X. Economic Impacts of Madrassa In District Larkana}

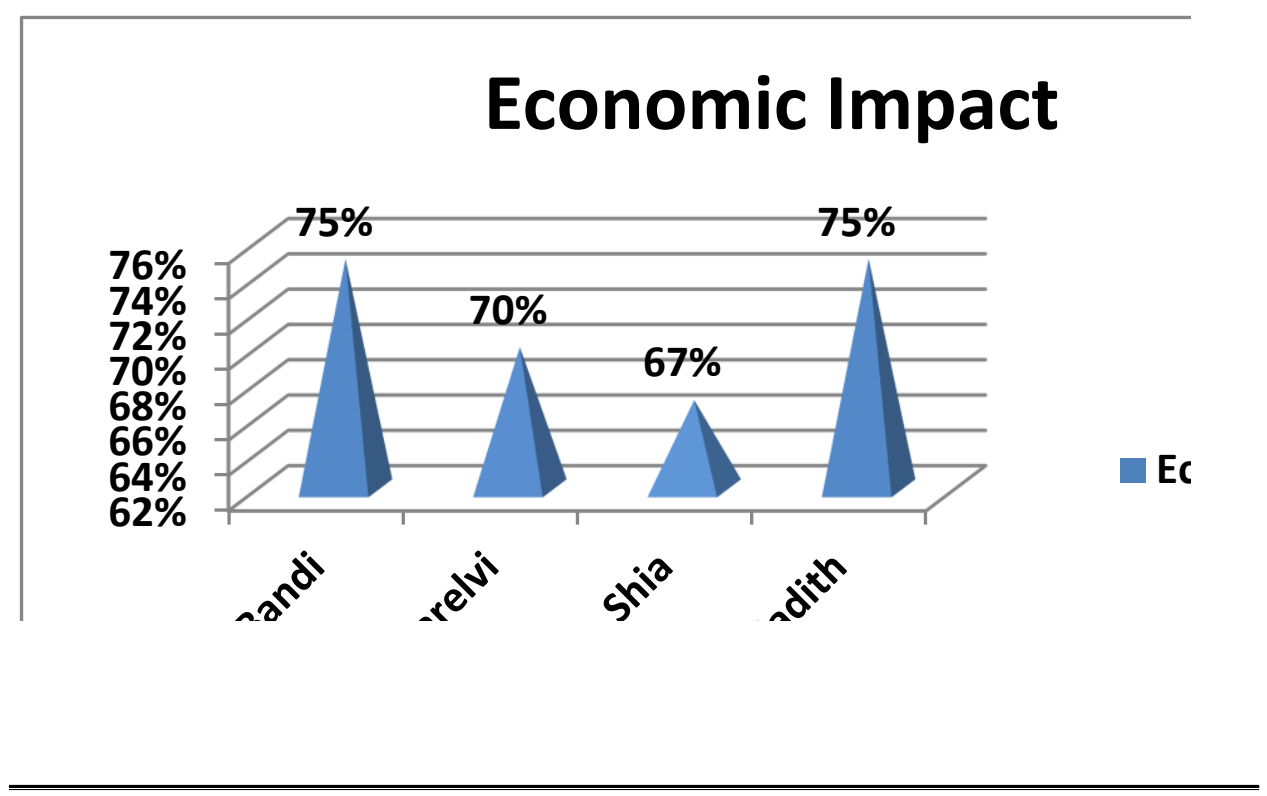




\section{CONCLUSION:}

The above analysis concludes that madrassas play a vital role in imparting education and economic benefits. Madrassas promote peace and harmony and the people associated with madrassas as students and alumni, and the people who are having jobs in madrasas. It is also suggested that the current secular course may be included in madrasas so that the sectarianism side of Madrassa may also be discouraged. There are a more significant number of different sects. Their madrassas in Larkana and Sindh province, the more substantial number of madrassas, and their education system help to increase the literacy rate is. The economy of people associate with madrasa is also growing.

\section{LIMITATION AND STUDY FORWARD:}

This research area is vast and needs to be studied further due to lack of time and limited facility and pandemic of COVID-19 researcher covered different impacts of the madrasa. This research finding focused on economic impacts only. Where a point of the study, the researcher covered economic, social, political, and educational implications of madrassas of Larkana division in his Ph.D. dissertation. It was also suggested for further research on this topic at the provincial and country level.

\section{ETHICAL CONSIDERATIONS:}

The research followed all the ethical principles of psychological research. the participants gave their consent, and the researcher ensures about 
The Scholar Islamic Academic Research Journal

Vol. 7, No. 1 || January -June 2021 || P. 1-31

https://doi.org/10.29370/siarj/issue12ar2

privacy and confidentially of the information obtained from the

participants

\section{ACKNOWLEDGEMENT:}

I would like to thanks, my teachers and friends. Fellows who supported me in completing this task, especially Dr. Imdad Hussain Sahito, Dr. Amir Ahmed Khuhro, further Siraj Ahmed Soomro, Allah Dino Mangrio, kept me morally during the pandemic of COVID-19. Their encouragement helped me to complete this task.

\section{(c)(1)(9) \\ BY NC SA This work is licensed under a Creative Commons}

Attribution-NonCommercial-ShareAlike 4.0 International (CC BY-NC-SA 4.0) 